\title{
UNA (OTRA) HISTORIA DE LA MODERNIDAD
}

\author{
LA LEY DEL RELOJ. ARQUITECTURA, MÁQUINAS Y \\ CULTURA MODERNA
}

Eduardo Prieto

Cátedra, Madrid, 2016

Eduardo Prieto, desde su doble condición de pertenencia a los campos de la arquitectura y de la filosofía, ha desarrollado una tarea "arqueológica" al develar, capa por capa, cómo fue que a lo largo de los últimos tres siglos la cultura occidental se ha visto atravesada por la metáfora de la máquina, que literal y simbólicamente impregnó grandes áreas del pensamiento, el diseño, el arte y la arquitectura. En el libro, el reloj funge como un amplio recurso alegórico: viene a cubrir el extenso universo maquínico que comienza a desplegarse en el siglo XVIII (que el texto desarrolla con detalle, sin descuidar una necesaria remisión a sus orígenes) hasta alcanzar una oportuna puesta al día en el epílogo.

Desde la ideología mecanicista de la Ilustración en adelante se desatan tensiones teóricas y prácticas, que en su confluencia tendrán derivas (algunas previsibles, otras inesperadas y casi siempre contradictorias) en la arquitectura. A partir de entonces, entre los extremos de una aceptación a ultranza de la técnica como motor de un progreso ilimitado (que encontraría en las máquinas y la industria su más enérgica representación), y de las radicales oposiciones luditas (o la negatividad fáustica que algunos pensadores atribuirían a su desarrollo), una extensa gama de matices circularon por carriles que van de las analogías poéticas a las imitaciones literales, el funcionalismo, el mecanicismo, la noción de sistemas o el utilitarismo sin más.

Con ello se configura un mundo que en las Exposiciones Universales -como señala Rafael Moneo en el prólogo- a mediados del siglo XIX comienza a globalizarse, invadiéndolo todo con una producción en la que, tal vez, los avances más interesantes podían encontrarse precisamente en aquello que la hacía posible (la máquina) y la ponía en circulación (el ferroca- 
rril). Energía, eficiencia y velocidad serían los inevitables parámetros de legitimación, que postulados desde la arquitectura tendrían sus equivalentes en las ideas de funcionalidad y racionalidad, a las que vendría a sumarse una correspondencia formal basada en geometrías puras y el abandono de los lenguajes del pasado.

La lógica de las máquinas de la Revolución Industrial en su -muchas veces aparente- pureza formal, activó el imaginario de los arquitectos de principios del siglo $\mathrm{XX}$ para nutrir un repertorio de nuevas formas $y$ materiales. Y no solo eso, sino que también amplió su registro simbólico, alcanzando cumbres de condensación retórica en frases tales como aquella de la "machine à habiter" - que obtuvo inusitada amplificación- o disparó un sinnúmero de experimentos convocando precisamente a la representación de los mencionados impulsos de energía y velocidad, con recursos formales de todo tipo.

Por un lado, la búsqueda de objetividad (otrora garantizada por un sistema clásico puesto en discusión, aunque aún activo) sería confiada a la exactitud del cálculo científico y la precisión técnica; por otro, la intención comunicativa abrevaría en las imágenes de las hidroeléctricas, los grandes generadores, las torres de alta tensión. En un punto de confluencia, se compartiría la fascinación por las grandes máquinas de la movilidad: el transatlántico, el automóvil, el ferrocarril y, la más significativa de todas, el aeroplano.

Pero así como a toda acción corresponde una reacción -que las hubo a cada momento-, el siglo XX tuvo sus propias miradas negativas sobre la cuestión central que articula estos procesos: la técnica. Las consecuencias no deseadas del desarrollo tecnológico serían el eje de profundos debates filosóficos y más tarde, y por distintas razones, acabarían impactando también sobre la arquitectura.

Es copiosa la información organizada en el texto, que se desplaza en una lectura fluida, son muchos los nombres convocados y acertadamente ubicados en la trama de movimientos estéticos, inventos tecnológicos, corrientes filosóficas y menciones bibliográficas que componen este tan apretado -como agudamente analizado- tejido de acontecimientos, pero con todo, no puede dejar de destacarse la cuidada y profusa selección de imágenes que, sumadas a una ágil diagramación, hacen necesaria la lectura de este libro que es también, a su modo, una historia de la modernidad.

\section{Luis Müller}

Arquitecto, Profesor de Historia en

FADU UNL, Santa Fe, Argentina 